\title{
ANALISIS PENGARUH PLATFORM SOSIAL MEDIA TERHADAP PENYEBARAN INFORMASI BENCANA
}

\author{
Rona Nisa Sofia Amriza ${ }^{1}$, Khairun Nisa Meiah Ngafidin ${ }^{2}$ \\ ${ }^{1,2}$ Program Studi Sistem Informasi Fakultas Informatika Institut Teknologi Telkom Purwokerto \\ Jl. D.I. Panjaitan No. 128, Purwokerto, Jawa Tengah \\ ${ }^{1}$ rona@ittelkom-pwt.ac.id \\ ${ }^{2}$ nisa@ittelkom-pwt.ac.id
}

\begin{abstract}
Abstrak- Sosial media menjadi platform yang sangat berperan dalam menyebarkan informasi, berita, dan memberikan informasi bencana secara cepat dan tepat. Banyak informasi berharga yang dapat diperoleh dalam platform ini. Penelitian ini menganalisis pengaruh platform sosial media terhadap intensi masyarakat untuk menyebarkan informasi bencana yang dipengaruhi oleh mediator personal yaitu altruisme dan efikasi diri. Penelitian ini mengobservasi penyebab seseorang memiliki intensi untuk menyebarkan informasi bencana. Structural Equation Modeling Partial Least Squares (SEM-PLS) digunakan untuk melakukan uji hipotesis. Dari penelitian ini kami menemukan bahwa mediator altruisme dan efikasi diri dalam platform sosial media berpengaruh secara signifikan terhadap intensi seseorang untuk menyebarkan informasi bencana.
\end{abstract}

Kata Kunci: Sosial Media, Penyebaran Informasi, Penyebaran Informasi Bencana, Structural Equation Modeling, Partial Least Squares, SEM-PLS

\section{PENDAHULUAN}

Sosial media seperti Facebook, Twitter, Instagram, dan Linkedin dalam satu dekade ini berkembang dengan amat pesat secara global, termasuk di Indonesia. Indonesia merupakan negara pengguna internet terbesar keempat di dunia. Pengguna internet di Indonesia mencapai 196,7 juta jiwa dan pengguna aktif media sosialnya mencapai 170 juta. Melalui jaringan virtual masyarakat menyebarkan berbagai informasi, hobi, opini, sikap dan informasi lainnya melalui komunikasi cepat [1]. Banyak masyarakat Indonesia memanfaatkan sosial media untuk menyebarkan informasi bencana, pada Februari 2021 banjir dan banjir Jakarta merupakan trending topik di media sosial Twitter [2].

Penyebaran informasi bencana yang relevan sangat penting pengaruhnya terhadap penanganan bencana. Penyebaran informasi yang cepat dapat membantu para pemangku kepentingan seperti pemerintah, Badan Penanggulangan bencana, serta NGO untuk menemukan dan menyelamatkan para korban, memberikan perawatan medis, serta memberikan bantuan kepada korban. Sosial media membantu komunikasi perseorangan ketika terjadi bencana, banyak informasi yang tidak terduga dapat didapatkan melalui komunikasi tersebut [3], ditambah lagi ketika terjadi bencana seseorang lebih cenderung menyebarkan informasi ke banyak orang [4].

Penelitian sebelumnya telah banyak membahas tentang penyebaran informasi bencana di sosial media [5,6,7] akan tetapi sebagian besar penelitian sebelumnya membahas tentang faktor personal seseorang dalam menyebarkan informasi bencana misalnya keinginan membantu sesama. faktor personal memang faktor yang sangat penting dalam menyebarkan informasi bencana karena mempelajari kemampuan dan keinginan seseorang dalam menyebarkan informasi. Penelitian sebelumnya masih belum ada yang membahas mengenai seberapa penting sosial media sebagai platform untuk menyebarkan informasi bencana. Untuk menanggulangi permasalahan tersebut, dalam penelitian ini, akan dilakukan analisis seberapa besar pengaruh platform sosial media dalam mempengaruhi keinginan seseorang dalam menyebarkan informasi bencana yang dipengaruhi oleh faktor personal seperti kemampuan seseorang dalam menggunakan sosial media dan keinginan seseorang dalam membantu 
sesama tanpa mengharapkan imbalan. Tujuan dari penelitian ini adalah mengetahui apakah mediator altruisme dan efikasi diri berpengaruh di platform sosial media berpengaruh secara positif terhadap keinginan seseorang dalam menyebarkan informasi bencana.

\section{METODOLOGI PENELITIAN}

Kerangka konseptual dibuat dari review literatur dari penelitian sebelumnya. faktor personal banyak digunakan oleh peneliti dalam penelitian sebelumnya untuk mengetahui seberapa besar keinginan seseorang membagikan informasi $[5,6,7]$ pada penelitian ini, faktor personal merupakan mediator untuk mengetahui apakah platform sosial media merupakan faktor yang berpengaruh terhadap keinginan seseorang dalam menyebarkan informasi bencana. Langkahlangkah penelitian yang digunakan dalam penelitian ini dapat dilihat pada gambar 1 .

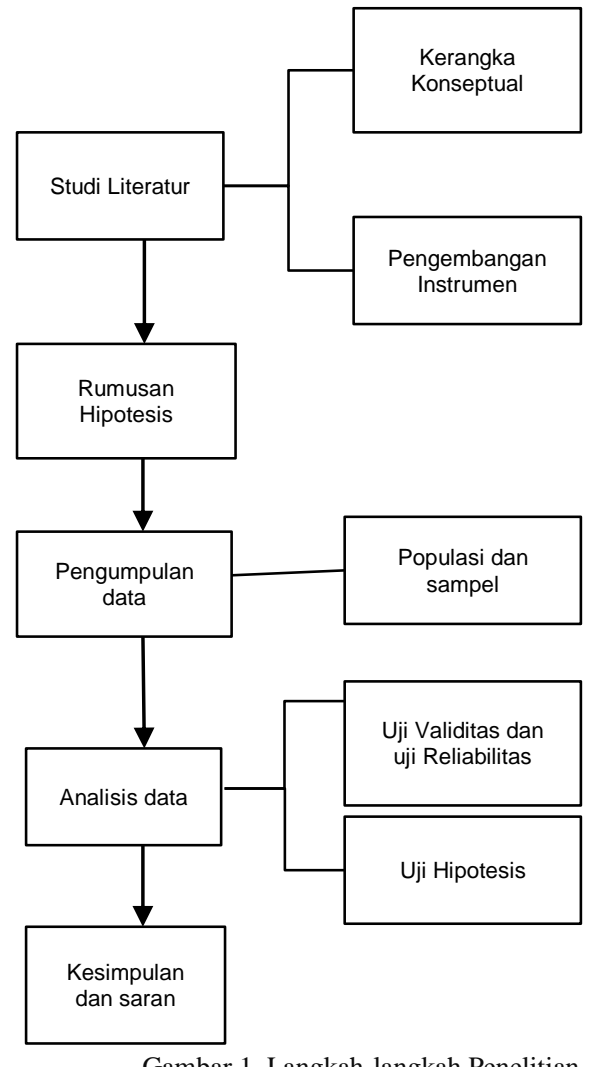

Gambar 1. Langkah-langkah Penelitian

Penelitian ini dimulai dengan studi literatur, dalam tahapan ini peneliti melakukan review literatur terhadap penelitian sebelumnya yang berkaitan dengan penyebaran informasi di sosial media. Faktor personal berpengaruh dalam penyebaran informasi di sosial media [5,6,7]. Altruisme merupakan salah satu faktor personal yang banyak diuji oleh penelitian sebelumnya yang berkaitan dengan penyebaran informasi di sosial media [8, 9, 10]. Altruisme adalah membantu orang lain tanpa mengharapkan imbalan [5]. [11] menemukan bahwa altruisme berpengaruh meningkatkan kepuasan dalam membagikan informasi di sosial media.

Efikasi diri merupakan faktor lain dalam faktor personal. Efikasi diri adalah kemampuan untuk melakukan dan menyelesaikan suatu pekerjaan [12]. Kemampuan seseorang untuk membagikan informasi kepada orang lainnya adalah suatu faktor yang dibutuhkan dalam menyebarkan informasi di media sosial. Semakin besar efikasi diri, maka semakin besar juga usaha yang dilakukan oleh seseorang untuk melaksanakan suatu aktivitas [6].

Platform sosial media itu sendiri merupakan bagian yang sangat penting dalam mempengaruhi seseorang dalam menyebarkan informasi bencana. Mengumpulkan dan menyebarkan informasi pada waktu yang tepat dan akurat selama krisis kebencanaan berlangsung merupakan hal yang sangat penting untuk meminimalkan dampak negatif yang dialami korban bencana. Semakin cepat seseorang dalam mengumpulkan, menganalisis dan menyebarkan informasi penting, semakin efektif pula respon yang dapat dilakukan dan semakin banyak nyawa yang dapat terselamatkan. [13] menemukan bahwa informasi yang dibagikan di sosial media Twitter pada saat bencana banjir terjadi sangat akurat karena pengguna Twitter tersebut tinggal di daerah itu dan mengetahui keadaan yang terjadi disana. Twitter sebagai salah satu platform sosial media memberikan informasi yang tepat waktu, andal, dan akurat, oleh sebab itu dalam penelitian ini platform sosial media yang akan digunakan sebagai objek penelitian adalah Twitter. Berdasarkan studi literatur dari berbagai penelitian yang sudah dilakukan sebelumnya, maka terbentuklah kerangka konseptual seperti pada gambar 2 .

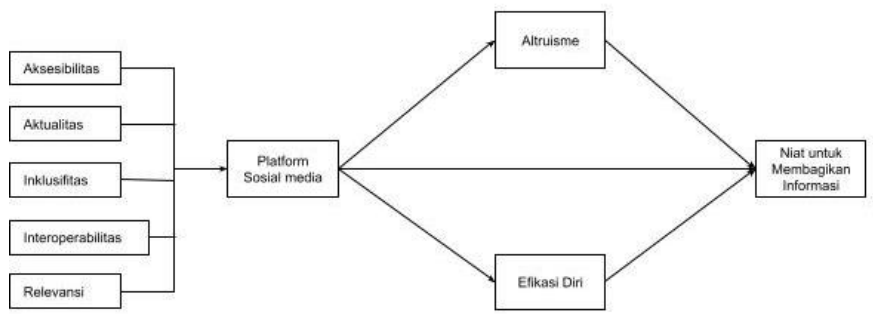

Gambar 2. Kerangka Konseptual

Rumusan hipotesis dalam penelitian ini adalah sebagai berikut:

H1 : Platform sosial media berpengaruh positif dan signifikan terhadap altruisme 
H2 : Platform Sosial Media berpengaruh positif dan signifikan terhadap efikasi diri

H3 : Altruisme berpengaruh positif dan signifikan terhadap intensi untuk menyebarkan informasi bencana

H4 : Efikasi diri berpengaruh secara positif dan signifikan terhadap intensi untuk menyebarkan informasi bencana

H5 : Platform sosial media berpengaruh positif dan signifikan terhadap intensi untuk menyebarkan informasi bencana

H6

: Altruisme memediasi pengaruh platform sosial media terhadap intensi untuk menyebarkan informasi bencana

: Efikasi diri memediasi pengaruh platform sosial media terhadap intensi untuk menyebarkan informasi bencana

Metode yang digunakan dalam penelitian ini adalah dengan menggunakan metode kuantitatif, metode kuantitatif mengandung paradigma positivist. dalam positivist sesuatu yang benar adalah sesuatu yang memiliki nilai positif dan dapat didapatkan dari prediksi atau dapat dilihat secara rasional. proses dalam positivis adalah mengamati fakta, merumuskan hipotesis dan melakukan uji statistik.

Populasi dalam penelitian ini adalah pengguna twitter yang ada di Indonesia. Sampel adalah responden yang merupakan subset dari populasi pengguna twitter di Indonesia yaitu sebesar 286. Teknik convenience sampling digunakan untuk menentukan jumlah sampel, convenience sampling merupakan teknik pengambilan sampel dengan memilih responden yang bersedia untuk mengisi kuisioner. kriteria responden dalam penelitian ini adalah pengguna Twitter yang pernah mengalami bencana.

Proses pengumpulan data dilakukan dengan menyebarkan kuesioner daring yang telah dibuat dengan menggunakan google form menggunakan skala likert 1 sampai 6.

Proses analisis data dengan melakukan uji validitas dan reliabilitas. Cronbach's alpha digunakan dalam uji reliabilitas data. Cronbach's alpha mengukur konsistensi internal, untuk mengetahui seberapa dekat kaitan suatu set item sebagai sebuah kelompok. Kriteria suatu data dapat dikatakan reliabel adalah apabila data tersebut memiliki nilai Cronbach's alpha lebih dari 0.7 [14]. Pengukuran reliabilitas juga dapat menggunakan composite reliability, jika nilai dari variabelnya lebih dari 0.7 maka variabel tersebut reliabel. Validitas data diukur dengan menggunakan validitas konvergen, jika outer loading item lebih dari 0.6 maka hal tersebut mengidentifikasikan bahwa ada lebih banyak varians bersama dibandingkan dengan varians error [15]. Average Variance Extracted (AVE) juga digunakan untuk mengukur validitas konvergen, apabila semua variabel memiliki nilai lebih dari 0,5 maka variabel tersebut valid. Selain validitas konvergen, dalam penelitian ini juga melakukan pengujian terhadap validitas diskriminan. validitas diskriminan diukur dengan membandingkan AVE dari setiap variabel dengan korelasi dari antar variabel nya. Jika nilai akar dari AVE dari setiap variabelnya melebihi nilai dari nilai korelasi antar variabel maka variabel tersebut valid. Pengujian validitas diskriminan juga dapat dilihat dari hasil nilai cross loading setiap indikator pertanyaan dari setiap variabelnya. Nilai cross loading indikator suatu konstruk lebih besar dari nilai cross loading dari konstruk lain maka validitas diskriminan setiap indikator terhadap variabelnya terpenuhi.

Uji hipotesis dilakukan dengan menggunakan Partial Least Squares (PLS). Hipotesis diuji dengan mengamati hasil nilai signifikan berdasarkan nilai path koefisien dan t-statistik. Penelitian ini menggunakan signifikan level 0.05 dan nilai kritikal sebesar 1.96. Selain itu juga dilakukan pengujian indirect effect, uji indirect effect dilakukan untuk mengetahui hubungan antara moderator, variabel independen dan variabel dependen.

\section{HASIL DAN PEMBAHASAN}

Data didapatkan dari kuesioner daring yang disebar oleh peneliti, dari data tersebut dilakukan uji validitas dan reliabilitas untuk mengukur ketepatan dan kecermatan dari instrumen penelitian yang diukur. Hasil uji validitas dan uji reliabilitas dapat dilihat pada tabel 1. Hasil pengujian reliabilitas menunjukkan bahwa semua variabel memenuhi kriteria yaitu nilai dari Cronbach's Alpha diatas 0.7 dan nilai Composite Reliability dari semua variabelnya juga diatas 0.7 . Hasil pengujian Validitas konvergen dapat diukur dengan menggunakan AVE, dari Tabel I dapat dilihat bahwa semua variabel diatas 0.5 .

TABEL I UJI RELIABILITAS DAN UJI VALIDITAS

\begin{tabular}{|c|c|c|c|c|c|}
\hline & $\begin{array}{c}\text { Cronbach's } \\
\text { Alpha }\end{array}$ & $C R$ & $\begin{array}{c}\text { Average } \\
\text { Variance } \\
\text { Extracted } \\
(A V E)\end{array}$ & Item & $\begin{array}{c}\text { Outer } \\
\text { Loading }\end{array}$ \\
\hline \multirow[t]{3}{*}{ Altruisme } & 0.75 & 0.86 & 0.67 & AL1 & 0.83 \\
\hline & & & & AL2 & 0.78 \\
\hline & & & & AL3 & 0.84 \\
\hline \multirow[t]{3}{*}{ Efikasi Diri } & 0.92 & 0.93 & 0.67 & ED1 & 0.82 \\
\hline & & & & ED2 & 0.79 \\
\hline & & & & ED3 & 0.84 \\
\hline
\end{tabular}




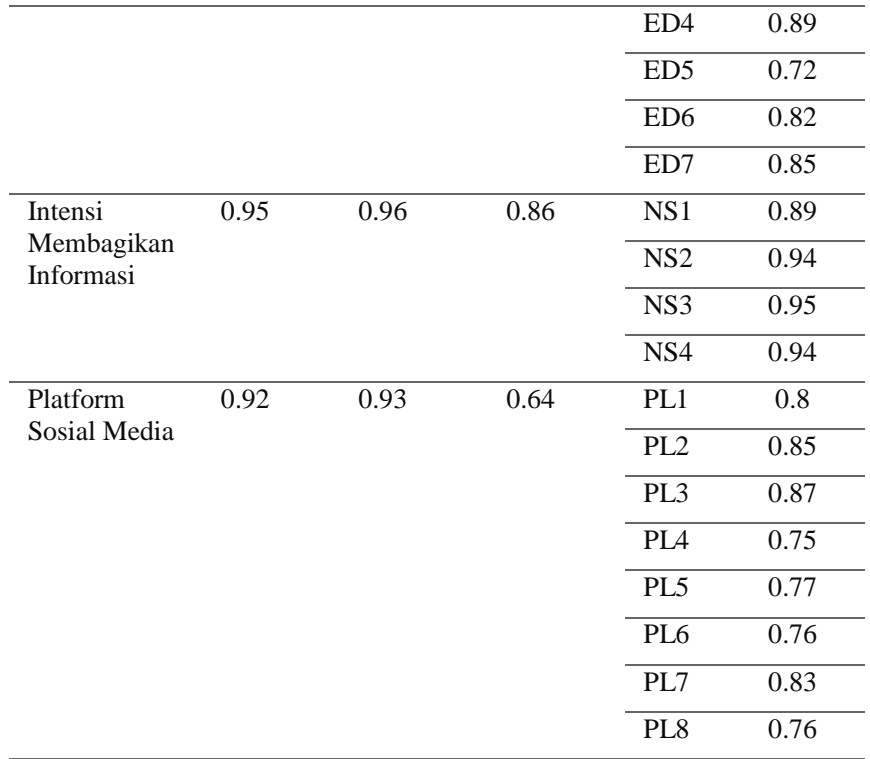

Uji validitas diskriminan dilakukan dengan membandingkan akar AVE dengan semua konstruknya. Tabel II menunjukkan bahwa akar dari AVE dari semua konstruk melebihi semua korelasi inter-konstruk.

TABEL II

VALIDITAS DISKRIMINAN

\begin{tabular}{lcccc}
\hline Altruisme & $\begin{array}{c}\text { Platform } \\
\text { Sosial } \\
\text { Media }\end{array}$ & $\begin{array}{c}\text { Intensi } \\
\text { Membagikan } \\
\text { Informasi }\end{array}$ & $\begin{array}{c}\text { Efikasi } \\
\text { Diri }\end{array}$ \\
\hline Altruisme & $\mathbf{0 . 8 2}$ & & &
\end{tabular}

$\begin{array}{lll}\text { Platform } & 0.52 & \mathbf{0 . 8}\end{array}$

Sosial Media

Intensi

$0.56 \quad 0.51$

0.93

Membagikan

0.36

0.41

0.36

0.82

Uji validitas diskriminan dalam penelitian ini juga menggunakan pengukuran cross loading. Tabel III menunjukkan bahwa semua item dari seluruh konstruk tidak merefleksikan konstruk lain, ditandai dengan item loading dari setiap konstruk lebih besar dari item loading di konstruk lain.

TABEL III CROSS LOADING

\begin{tabular}{|l|c|c|c|c|}
\hline & Altruisme & $\begin{array}{c}\text { Platform Sosial } \\
\text { Media }\end{array}$ & $\begin{array}{c}\text { Intensi } \\
\text { Membagikan } \\
\text { Informasi }\end{array}$ & Efikasi Diri \\
\hline PL1 & 0.39 & $\mathbf{0 . 8}$ & 0.4 & 0.3 \\
\hline PL2 & 0.44 & $\mathbf{0 . 8 5}$ & 0.4 & 0.3 \\
\hline PL3 & 0.43 & $\mathbf{0 . 8 7}$ & 0.41 & 0.32 \\
\hline PL4 & 0.43 & $\mathbf{0 . 7 5}$ & 0.41 & 0.34 \\
\hline
\end{tabular}

\begin{tabular}{|l|c|c|c|c|}
\hline PL5 & 0.49 & $\mathbf{0 . 7 7}$ & 0.42 & 0.32 \\
\hline PL6 & 0.39 & $\mathbf{0 . 7 6}$ & 0.36 & 0.31 \\
\hline PL7 & 0.37 & $\mathbf{0 . 8 3}$ & 0.4 & 0.3 \\
\hline PL8 & 0.41 & $\mathbf{0 . 7 6}$ & 0.45 & 0.39 \\
\hline AL1 & $\mathbf{0 . 8 3}$ & 0.41 & 0.44 & 0.21 \\
\hline AL2 & $\mathbf{0 . 7 8}$ & 0.44 & 0.52 & 0.34 \\
\hline AL3 & $\mathbf{0 . 8 4}$ & 0.43 & 0.41 & 0.33 \\
\hline ED1 & 0.31 & 0.37 & 0.31 & $\mathbf{0 . 8 2}$ \\
\hline ED2 & 0.25 & 0.35 & 0.26 & $\mathbf{0 . 7 9}$ \\
\hline ED3 & 0.29 & 0.33 & 0.29 & $\mathbf{0 . 8 4}$ \\
\hline ED4 & 0.29 & 0.32 & 0.29 & $\mathbf{0 . 8 9}$ \\
\hline ED5 & 0.37 & 0.38 & 0.38 & $\mathbf{0 . 7 2}$ \\
\hline ED6 & 0.27 & 0.24 & 0.24 & $\mathbf{0 . 8 2}$ \\
\hline ED7 & 0.27 & 0.28 & 0.24 & $\mathbf{0 . 8 5}$ \\
\hline NS1 & 0.51 & 0.5 & $\mathbf{0 . 8 9}$ & 0.37 \\
\hline NS2 & 0.52 & 0.45 & $\mathbf{0 . 9 4}$ & 0.31 \\
\hline & 0.54 & 0.47 & $\mathbf{0 . 9 5}$ & 0.33 \\
\hline
\end{tabular}

Uji Hipotesis dilakukan menggunakan Partial Least Square (PLS). Tabel IV menunjukkan level signifikan dari tstatistik dan $p$-value, Semua hipotesis terpenuhi dengan hasil $\alpha$ kurang dari 0.05 atau kurang dari 0.01. Satu hipotesis diterima pada $p$-value 0.01 dan empat hipotesis diterima pada $p$-value 0.05 .

TABEL IV

UJI HIPOTESIS

\begin{tabular}{lccccc}
\hline & $\begin{array}{c}\text { Original } \\
\text { Sample } \\
(O)\end{array}$ & $\begin{array}{c}\text { Sample } \\
\text { Mean } \\
(M)\end{array}$ & $\begin{array}{c}\text { Standard } \\
\text { Deviation } \\
(\text { STDEV })\end{array}$ & $\begin{array}{c}\text { T Statistics } \\
(\mid \text { OSTDEV } \mid)\end{array}$ & P Values \\
\hline $\begin{array}{l}\text { H1: Sosial } \\
\text { Media Platform } \\
\rightarrow \text { Altruisme }\end{array}$ & 0.52 & 0.53 & 0.06 & $9.45^{* * *}$ & 0 \\
\hline $\begin{array}{l}\text { H2: Sosial } \\
\text { Media Platform } \\
\rightarrow \text { Efikasi Diri }\end{array}$ & 0.41 & 0.41 & 0.06 & $7.16^{* * *}$ & 0 \\
\hline $\begin{array}{l}\text { H3: Altruisme } \\
->\text { Intensi }\end{array}$ & 0.39 & 0.39 & 0.06 & $6.55^{* * *}$ & 0 \\
$\begin{array}{l}\text { Menyebarkan } \\
\text { Informasi }\end{array}$ & & & & & 0 \\
\hline
\end{tabular}




\begin{tabular}{lccccc}
\hline $\begin{array}{l}\text { H4: Efikasi } \\
\text { Diri - Intensi } \\
\text { Menyebarkan } \\
\text { Informasi }\end{array}$ & 0.11 & 0.12 & 0.05 & $2.22^{*}$ & 0.01 \\
\hline $\begin{array}{l}\text { H5: Sosial } \\
\text { Media Platform }\end{array}$ & 0.26 & 0.25 & 0.05 & $4.97 * *$ & 0 \\
$\begin{array}{l}\rightarrow \text { Intensi } \\
\text { Menyebarkan } \\
\text { Informasi }\end{array}$ & & & & & \\
\hline
\end{tabular}

\section{Analisis Partial Least Square (PLS)}

H1 : Platform sosial media berpengaruh positif dan signifikan terhadap altruisme

Pengaruh langsung platform sosial media terhadap altruisme dengan nilai 0.52 dan t-statistik 9.45 . Nilai t-statistik lebih besar dari 1.96 maka hipotesis 1 diterima. Sosial media sebagai platform yang mudah digunakan, tepat waktu, dapat diandalkan dan memberikan informasi yang akurat dapat berpengaruh positif terhadap seseorang yang ingin membantu sesama tanpa mengharapkan imbalan.

H2 : Platform Sosial Media berpengaruh positif dan signifikan terhadap efikasi diri

Platform sosial media berpengaruh secara positif dan signifikan terhadap efikasi diri, ditunjukkan dengan nilai 0,41 dan t-statistik 7.16. Nilai t-statistik lebih dari 1.96 maka hipotesis 2 diterima. Platform sosial media merupakan platform yang mudah digunakan sehingga berpengaruh positif terhadap kemampuan seseorang untuk menyelesaikan suatu pekerjaan, dengan sosial media mudah untuk diakses maka seseorang juga akan mudah untuk menyelesaikan pekerjaanya.

H3 : Altruisme berpengaruh positif dan signifikan terhadap intensi untuk menyebarkan informasi bencana Altruisme merupakan membantu orang lain tanpa mengharapkan imbalan, dalam konteks situasi bencana seseorang memiliki intensi yang kuat untuk membantu sesama dengan menyebarkan informasi bencana. Seseorang yang memiliki altruisme tinggi memiliki kecenderungan untuk membantu sesama dengan menyebarkan informasi bencana. Sejalan dengan penelitian dari [9] seseorang akan lebih termotivasi untuk menyebarkan informasi karena mereka ingin membantu sesama yang membutuhkan informasi atau mereka peduli dengan berbuat baik tanpa pamrih. Hipotesis 3 diterima karena memiliki nilai 0,39 dan t-statistik diatas 1.96 yaitu 6.55 .

H4 : Efikasi diri berpengaruh secara positif dan signifikan terhadap intensi untuk menyebarkan informasi bencana

Pengaruh langsung efikasi diri terhadap intensi menyebarkan informasi bencana dengan nilai 0,11 dan t-statistik 2.22 .
Hipotesis 4 diterima karena nilai t-statistik lebih dari 1.96 . efikasi diri signifikan terhadap intensi menyebarkan informasi bencana. Seseorang yang memiliki efikasi diri tinggi, lebih memiliki kecenderungan untuk membantu sesama dibandingkan dengan seseorang yang memiliki efikasi diri rendah [38].

H5 : Platform sosial media berpengaruh positif dan signifikan terhadap intensi untuk menyebarkan informasi bencana

Platform sosial media mempunyai pengaruh yang sangat penting dalam penyebaran informasi bencana. Penelitian ini menemukan bahwa platform sosial media berpengaruh positif dan signifikan terhadap intensi seseorang untuk menyebarkan informasi bencana ditunjukkan dengan nilai 0,26 dan tstatistik yang lebih dari 1.96 yaitu 4.97. Berdasarkan nilai tersebut dapat diambil kesimpulan bahwa hipotesis 5 diterima.

H6 : Altruisme memediasi pengaruh platform sosial media terhadap intensi untuk menyebarkan informasi bencana Pengujian indirect effect dilakukan untuk mengetahui apakah mediasi tersebut mediasi sempurna atau mediasi parsial. Berdasarkan hasil pengujian indirect effect hipotesis 6 diterima karena altruisme berpengaruh positif dan signifikan terhadap pengaruh platform sosial media terhadap intensi seseorang untuk menyebarkan informasi bencana ditandai dengan nilai t-statistik yang lebih dari 1.96 yaitu 5.37 dan mediasi tersebut merupakan mediasi parsial karena Dalam situasi bencana, media sosial merupakan Platform yang mudah untuk dipakai, reliabel, dan cepat dalam menyebarkan informasi, hal sebut menyebabkan seseorang memiliki intensi untuk menyebarkan informasi bencana dan secara positif dipengaruhi oleh keinginan seseorang untuk membantu sesama dalam situasi bencana.

H7 : Efikasi diri memediasi pengaruh platform sosial media terhadap intensi niat untuk menyebarkan informasi bencana

Hasil pengujian indirect effect menunjukkan bahwa mediasi parsial karena mediator secara statistik signifikan, hal tersebut dapat dilihat dari nilai t-statistik yaitu sebesar 1.96. Hipotesis 7 diterima. Kemudahan dalam menggunakan platform media sosial berpengaruh secara signifikan dalam intensi seseorang dalam menyebarkan informasi bencana dan secara positif dipengaruhi oleh mediator efikasi diri, seseorang akan memiliki intensi untuk menyebarkan informasi bencana karena platform sosial media yang mudah digunakan dan orang tersebut memiliki kemampuan untuk melakukan pekerjaan tersebut. 
TABEL V

UJI PENGARUH MEDIASI

\begin{tabular}{l|c|c|c|c|} 
& $\begin{array}{c}\text { Specific } \\
\text { Indirect } \\
\text { Effects }\end{array}$ & $\begin{array}{c}\text { Standard } \\
\text { Deviation } \\
(\text { STDEV })\end{array}$ & $\begin{array}{c}\text { T Statistics } \\
(\mid \text { O/STDEV })\end{array}$ & P Values \\
\hline $\begin{array}{l}\text { H6 : Platform } \\
\text { Sosial Media } \\
\text {-> Altruisme } \\
\text {-> Intensi } \\
\text { menyebarkan }\end{array}$ & 0.2 & 0.04 & 5.37 & 0 \\
Informasi & & & & \\
\hline $\begin{array}{l}\text { H7 : Platform } \\
\text { Sosial Media } \\
\text { - Efikasi }\end{array}$ & 0.05 & 0.02 & 1.96 & 0.03 \\
$\begin{array}{l}\text { Diri - Intensi } \\
\text { menyebarkan } \\
\text { Informasi }\end{array}$ & & & & \\
\hline
\end{tabular}

IV. KESIMPULAN

Berdasarkan hasil analisis yang telah dijabarkan pada bab hasil dan pembahasan, maka dapat disimpulkan bahwa terdapat lima hipotesis diterima dengan signifikansi tinggi, hipotesis tersebut adalah H1,H2,H3,H5, dan H6. Signifikansi tinggi terjadi karena kelima hipotesis tersebut diterima pada $p$ value 0.01. Sedangkan $\mathrm{H} 4$ dan $\mathrm{H} 7$ memiliki signifikansi cukup karena diterima pada p-value 0.05. Semua Hipotesis diterima dan tidak ada hipotesis yang ditolak. Dari Semua pengukuran yang telah dilakukan, dimulai dengan pengukuran langsung yang menguji signifikansi antar variabel dapat ditarik kesimpulan bahwa platform sosial media, altruisme, dan efikasi diri memiliki pengaruh positif terhadap intensi seseorang dalam menyebarkan informasi bencana. Pengujian tidak langsung juga dilakukan untuk mengetahui pengaruh mediator altruisme dan efikasi diri terhadap pengaruh platform sosial media terhadap intensi seseorang dalam menyebarkan informasi bencana. kedua mediator tersebut berpengaruh secara signifikan terhadap pengaruh platform media sosial terhadap intensi seseorang menyebarkan informasi bencana. Hal tersebut menunjukkan bahwa faktor personal dari dalam diri kita berpengaruh signifikan dalam intensi menyebarkan informasi bencana dan didukung dengan kemudahan yang ditawarkan oleh platform sosial media.

\section{UCAPAN TERIMA KASIH}

Terima kasih kami ucapkan kepada para responden yaitu para pengguna Twitter yang telah mengisi kuisioner dalam penelitian ini, sehingga penelitian ini dapat berjalan dengan lancar, dapat selesai dan dipublikasikan.

\section{REFERENSI}

[1] Martí P, Serrano-Estrda L, Nolasco-Cirugeda A, "Social media data: challenges, opportunities and limitations in urban studies", Computers, Environment and Urban System. 74, p. 161-174, 2018.

[2] Petabencana, "As Jakarta floods again, humanitarian chatbots on social media support community-led disaster response", info.petabencana.id, 22, February, 2021. [online]. Available: https://info.petabencana.id/2021/02/22/as-jakarta-floods-againhumanitarian-chatbots-on-social-media-support-community-leddisaster-response/.

[3] J. Sutton, L. Palen, and I. Shklovski, "Backchannels on the frontlines: emergent uses of social media in the 2007 Southern California wildfires," Proc. ISCRAM Conf., Washington, D.C, 2008.

[4] Sheedy, C. S, Social media for social change: A case study of social media use in the 2011 Egyptian revolution. Capstone Project, 28(4), 1$58,2011$.

[5] Oh and S. Y. Syn, "Motivations for sharing information and social support in social media: A comparative analysis of Facebook, Twitter, Delicious, YouTube, and Flickr," Journal of the Association for Information Science and Technology, vol. 66, no. 10, pp. 2045-2060, 2015

[6] J. Kim, C. Lee, and T. Elias, "Factors affecting information sharing in social networking sites amongst university students: Application of the knowledge-sharing model to social networking sites," Online Information Review, vol. 39, no. 3, pp. 290-309, 2015.

[7] M. Ahmad, N. M. Zani and K. F. Hashim, "Knowledge sharing behavior among flood victims in Malaysia" ARPN Journal of Engineering and Applied Sciences, vol. 10, no. 3, pp. 968-976, 2015.

[8] S. Kuznetsov, "Motivations of contributors to Wikipedia," $A C M$ SIGCAS computers and society, vol. 36, no. 2, pp. 1-7, 2006.

[9] C. L. Hsu and J. C. C. Lin, "Acceptance of blog usage: The roles of technology acceptance, social influence and knowledge sharing motivation," Information \& management, vol. 45, no. 1, pp. 65-74, 2008

[10] S. Rafaeli, T. Hayat and Y. Ariel, "Wikipedia community: Users' motivations and knowledge building," In cyberculture 3rd global conference, 2005, Prague, Czech Republic.

[11] S. Y. Hung, A. Durcikova, H. M. Lai and W. M. Lin, "The influence of intrinsic and extrinsic motivation on individuals' knowledge sharing behavior," International Journal of Human-Computer Studies, vol. 69 no. 6, pp. 415-427, 2011.

[12] A. Bandura, Self-Efficacy, in Encyclopedia of Human Behavior, New York: Academic Press, 1994.

[13] A. Kongthon, C. Haruechaiyasak, J. Pailai and S. Kongyoung, "The role of Twitter during a natural disaster: Case study of 2011 Tha Flood," in Proc. Technology Management for Emerging Technologies (PICMET), pp. 2227-2232, 2012.

[14] K. M. Loewenthal, An introduction to psychological tests and scales London: Psychology Press, 2018.

[15] J. F. Hair Jr, W. C. Black, B. J. Babin and R. E. Anderson, Multivariate data analysis $\left(7^{\text {th }}\right.$ edition$)$, UK: Pearson Prentice Hall. 